\title{
History of an irrigation canal: the 'Real Canal de la Infanta', Barcelona, Spain
}

\section{Jose Luis de la Peña}

Departamento de Aguas y Alcohol, Instituto Grifols,

S.A. C/Can Guasch, 2. 08150, Parets del Vallès, Spain

Email: jdlapena@grifols.com

\section{Miquel Salgot*}

Unitat d'Edafologia,

Facultat de Farmàcia,

Spain

and

Water Research Institute,

University of Barcelona,

Joan XXIII s/n, 08028 Barcelona, Spain

Email: salgot@ub.edu

*Corresponding author

\begin{abstract}
A great agricultural development took place in the Llobregat river delta, near Barcelona, during the 19th century in order to fulfil the demand of the growing town and even to export vegetables and fruits to the north of Europe. This demand favoured the transformation of dry land agriculture into irrigated one through the construction of infrastructures for water distribution. In the lower part of the Llobregat river, a canal for supplying water to agricultural fields was built supported by the authorities and landowners. The Infanta Luisa Carlota de Borbón Canal (Infanta Canal) was $17 \mathrm{~km}$ long with several complementary minor canals and distribution facilities to irrigate around 3,000 hectares which allowed at least three crops per year. Apart from irrigation and industrial uses, this system was used to generate electricity. Over the years, agriculture disappeared from the area due to industrialisation and urban growth and the canal was partially transformed into a sewer. Its trace has been lost near the Mediterranean Sea, although there are still some remnants. Nowadays, several teams are trying to describe and recover this historical facility.
\end{abstract}

Keywords: Infanta Luisa Carlota Royal Canal; Infanta Canal; industrialisation; urbanisation; agricultural decline; Barcelona; Spain.

Reference to this paper should be made as follows: de la Peña, J.L. and Salgot, M. (2016) 'History of an irrigation canal: the 'Real Canal de la Infanta', Barcelona, Spain', Int. J. Global Environmental Issues, Vol. 15, Nos. 1/2, pp.169-178. 
Biographical notes: Jose Luis de la Peña holds a degree in Geology and a degree in Pharmacy. He has been working across all water items, from the hydrogeological studies, to production of ultrapure water for hospital purposes, through prospecting, drinking water, and wastewater secondary and advanced treatments. He has published several papers in technical journals and taught courses to professionals of different fields or university masters. He is currently combining his work in the pharmaceutical industry, with historical water research at the Roman Empire remnants in the Imperial Tarraco (now Tarragona, Spain).

Miquel Salgot received his Pharmacy degree (1973) and PhD in Pharmacy (1981) from UB, University of Barcelona. He was an Associated Professor (1986) on Soil Science and Agricultural Chemistry in the Natural Products, Vegetal Biology and Soil Science Department, University of Barcelona. His research interest focuses on wastewater treatment, reclamation and reuse. $\mathrm{He}$ has published more than 100 papers and book chapters in international journals and other scientific publications. He has been participating in several EU funded projects as well as in national ones. At present, he is an Associate Editor of Water Research and reviewer of a number of scientific journals.

This paper is a revised and expanded version of a paper entitled 'The 'Real Canal de la Infanta' in Barcelona, Spain' presented at the IWA Regional Symposium on Water, Wastewater and Environment: Traditions and Culture, Patras, Greece, 22-24 March 2014.

\section{Introduction}

Agriculture before 18th century in Europe used to be mainly of subsistence, with few crop surpluses which were sold by farmers in order to obtain tools for cultivation and additional food. The towns were not heavily populated so the need for foodstuffs could easily be fulfilled from neighbouring agricultural areas or by gaming and fishing.

The change of urban models in relation with the industrial revolution at the end of 18th and beginning of 19th centuries transformed the agronomy-related infrastructures. The relationship between towns and surrounding areas changed suddenly and required new approaches to fulfil the needs for food of the ever-increasing number of urban inhabitants. New transportation infrastructures allowed to supply agricultural and cattle products from distant places.

Additionally, the growth of cities after the demolition of medieval walls and the great migrations from the countryside occupied the agricultural lands close or inside the cities. At the same time, farmers started to cultivate further away, at bigger scale, vegetables and fruit trees, easily sold in the markets.

The Mediterranean towns could be defined in terms of surface occupied and water availability. In terms of surface, there has usually been a tendency to concentrate houses in comparatively scarce surfaces, which generates a high density of inhabitants per area. This type of cities has been evolving from an old downtown and its expansion has been in part depending on the flat surface available, which usually coincided with the areas with the best soils for cultivation.

The Mediterranean towns still tend to concentrate houses in comparatively scarce surfaces, which generate a comparatively high density of population and difficulties for 
water supply. Then, until the 19th century, water availability in terms of quantity and quality was also conditioning Mediterranean towns' growth. There were limited amounts of water resources available for drinking, cooking and other uses, apart from the agricultural needs of the surrounding areas. Water quality and quantity were also important in relation to the health of the inhabitants. At the same time, water was also needed to start irrigating all the cultivable lands for increasing the yields. It was more profitable when markets to sell the products were located within distances reachable in a few hours.

Several towns in the Mediterranean area, mainly the ones with important industrial activity, experienced a great increase of population. So the improvement of agricultural performances and the capacity for supplying fresh food to the cities were essential. The example of Barcelona can be taken: an area where the flat valleys of the two surrounding rivers (Besòs and Llobregat) were fully put into irrigation. That time was favourable for landowners, who exerted an important influence on the transformation of agricultural lands: the rain-based agriculture changed to an irrigation-based one.

The local landowners were usually well related with the authorities or were authorities themselves. The landlords on the Southwest side of Barcelona, besides the Llobregat river, decided to build an irrigation canal near the beginning of the Llobregat delta at the town of Molins de Rei. In Spain, at that time, water management depended on the military authorities because water availability was considered a safety issue. This concept of water safety in terms of quantity lasted as far as to the half of 20th century when the water authority shifted to civil authorities (environment and health).

Landowners contacted captain general of Catalonia, Francisco Javier Castaños and asked him to perform the necessary actions to supply water to the lower Llobregat valley, until the moment devoted to dry farming, in order to transform agricultural surfaces into irrigated areas, where several crops per year could be implemented due to the mild climate and adequate soil. The vicinity of Barcelona made even more attractive the project in terms of business.

Their demand consisted in the commitment of a canal transporting water from the Llobregat river at Molins de Rei to the sea. This water should be mainly used for irrigation purposes.

The crown owned the rights to build canals but a royal decree (19 March 1810) revoked the law in order to favour the construction of hydraulic infrastructures by private investments. In this way, the royal assets renounced to its exclusivity. Nevertheless, the Decree was repealed in the year 1824, but the canal was already built and being used.

From 1810 to 1824 , General Castaños was the big promoter of the facility, although the cost was assumed by the landowners. The change of dry land cultures to high revenue ones and the increased number of crops per year caused a higher wealth state in the area. Additionally, part of the existing wetlands in the area was desiccated to gain agricultural land, which at the same time improved the health status of the population, less decimated by malaria and other water-related illnesses.

The project of the canal was presented on 29 August 1817. The authorisation for building it was granted quite immediately by a royal order (2 September 1817) and the channel to be named initially General Castaños, was finally the Royal Canal of her Serene Highness the Infanta Luisa Carlota de Borbón, but quickly the canal was known as 'Canal de la Infanta'.

The quick permission to build the canal was perhaps due in part to the extreme drought that the area was suffering, since 1817 was known as the year of famine in 
Barcelona and the low Llobregat region, also coinciding with a yellow fever epidemic. It is to note that from July 1816 up to May 1817 , no rain was recorded in the mid and lower valley of the river, but a few hailstorms. In 1817 only $196 \mathrm{~L} / \mathrm{m}^{2}$ were recorded in comparison with usual amounts of rain of $500 \mathrm{~L} / \mathrm{m}^{2}$ or more per year. The parishes of the area organised processions praying to Lord for the gift of rain but without any success. Those prayers have been reproduced several times in occasion of severe droughts and were even suggested by politicians in the 21 st century (Suriol, 2003).

\section{The commitment of the canal}

The works for building the canal started few days after the official approval, but very soon there appeared coordination problems as well as some resentment among the landlords for several reasons, mainly economic. All the mentioned and several unforeseen technical difficulties, raised the budget $50 \%$, from three million 'reales' to nearly 4.5 million reales.

It was agreed that the landlords should pay in proportion to the amount of land of their properties to be irrigated. An added problem was the reclamation issued by the millers of El Papiol and Molins de Rei on the use of water rights they owned. To solve any conflict mill owners were authorised to generate energy by using several waterfalls on the finished works.

The facility, although unfinished, was inaugurated on 21 May 1819, because the Infanta Luisa Carlota de Borbón was visiting Barcelona to attend a ball.

Figure 1 Map of the Canal De La Infanta, 1908 (see online version for colours)

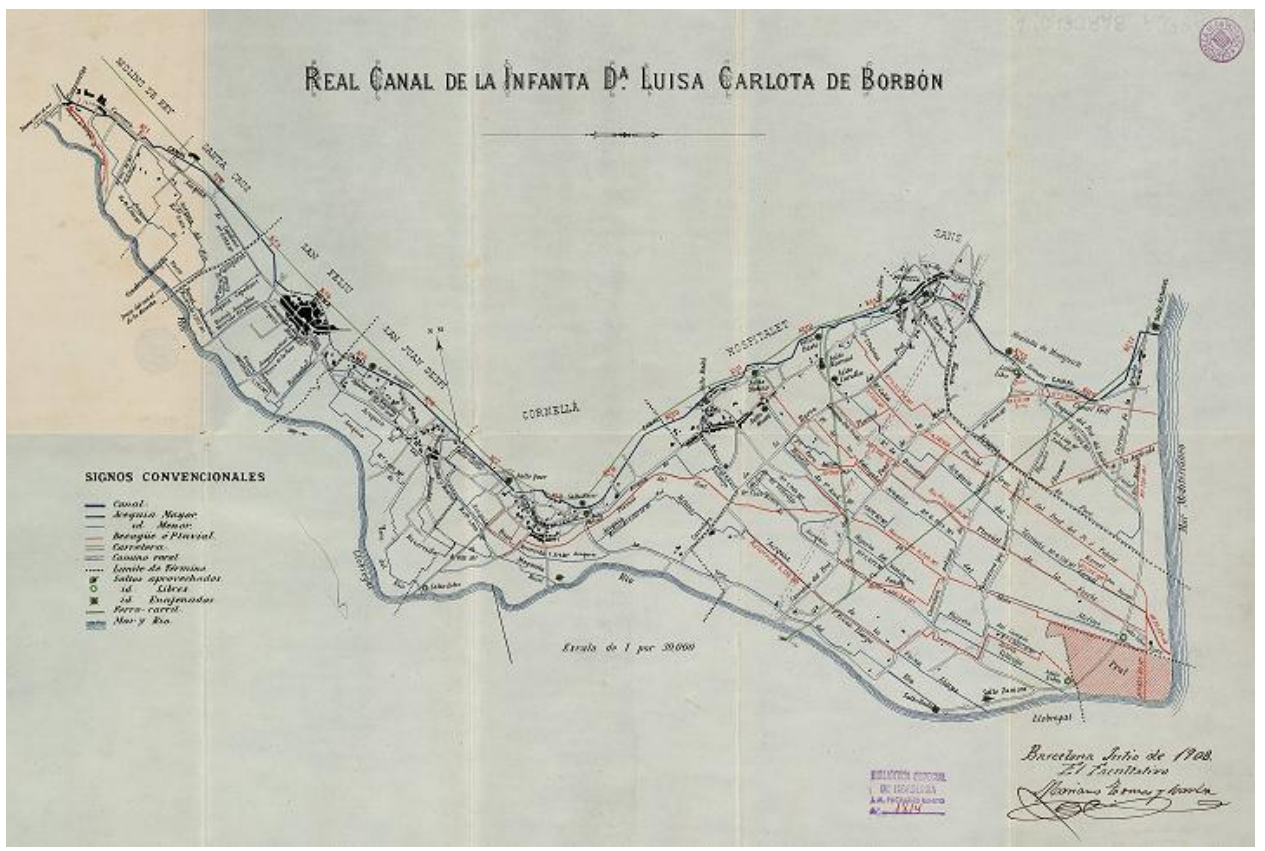

Source: ICC (2013) 
The main canal, as indicated (Figure 1), must have $17 \mathrm{~km}$ in length, 4 to $2.5 \mathrm{~m}$ width and $1.5 \mathrm{~m}$ depth with a $13.65 \mathrm{~m}$ descent carrying an estimated volume of water of $4 \mathrm{~m}^{3} / \mathrm{s}$. Several galleries were built, reaching $1.3 \mathrm{~km}$ length. A network of $25 \mathrm{~km}$ of secondary canals irrigated 3,000 hectares of cultivable land.

The canal left the house of gates (Figure 2) in Molins de Rei town and catched the remnant, excess waters from the mills in town that used to return to the river. At present, the house of gates is a listed building and considered part of the Catalan heritage.

The amount of water flowing in the canal was controlled from the building facilities and, if necessary, the gates could be closed for cleaning the canals.

Figure 2 The house of gates at Molins de Rei, nowadays inside the town (see online version for colours)

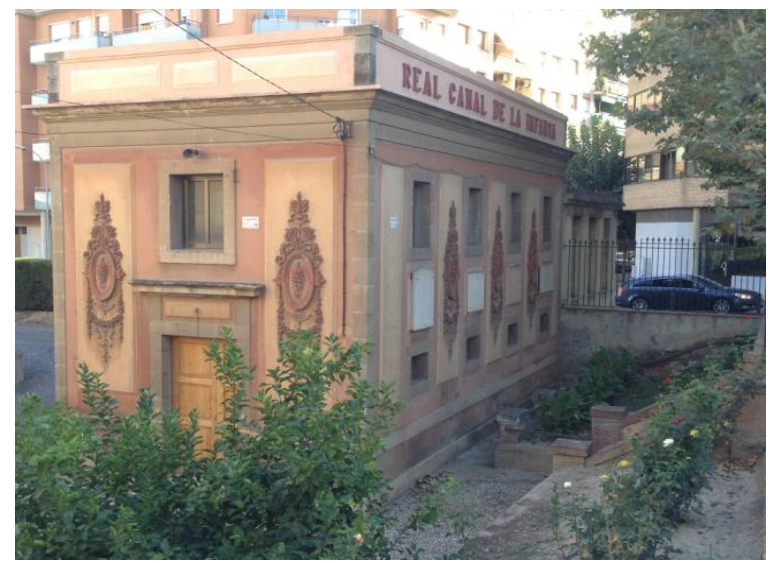

Table 1 Waterfalls in the Infanta Canal and its auxiliary canals at the time of the commitment

\begin{tabular}{lccc}
\hline $\begin{array}{l}\text { Main canal } \\
\text { waterfalls }\end{array}$ & Municipality & $\begin{array}{c}\text { Auxiliary canals } \\
\text { waterfalls }\end{array}$ & Municipality \\
\hline Erasmo & St. Joan Despí & Molino & Hospitalet de Llobregat \\
Quer & Cornellà de Llobregat & Munté & Hospitalet de Llobregat \\
Roses & Cornellà de Llobregat & Mármol & Hospitalet de Llobregat \\
Molí & Cornellà de Llobregat & Carulla & Hospitalet de Llobregat \\
Baltà & Hospitalet de Llobregat & Badal & Cornellà de Llobregat \\
Basté & Hospitalet de Llobregat & Zamora & Cornellà de Llobregat \\
Libre & Hospitalet de Llobregat & Magarola & Cornellà de Llobregat \\
Lleonard & Hospitalet de Llobregat & & \\
Libre & Sants (now Barcelona) & & \\
Bordeta & Sants (now Barcelona) & & \\
Romaní & Sants (now Barcelona) & & \\
Antúnez & At the seaside in & & \\
& Barcelona & & \\
\hline
\end{tabular}

In order to honour the agreement with millers, to cope with level changes and to generate energy, small waterfalls were built in the main and secondary canals (Table 1) as well as 
minor ones not generating energy. The amount of energy produced was estimated as 262 HP per year (http://bellvitgejose.blogspot.com.es/).

At that time the canal started officially at the house of gates, in part catching water from the Ferrer i Mora canal, which in turn was supplied by another canal from the Llobregat River, crossing through the town (Molins de Rei, Figure 3). Afterwards the main canal turned eastwards to reach the neighbouring town of Sant Feliu de Llobregat, where at present is covered. On its way to the sea, the canal used to cross several municipalities (Figure 1): Molins de Rei, Santa Creu d'Olorda (now pertaining to Barcelona municipality), Sant Feliu de Llobregat, Sant Joan Despí, Cornellà, Hospitalet de Llobregat and Sants (now pertaining to Barcelona municipality).

Figure 3 The Infanta Canal crossing Molins de Rei (see online version for colours)

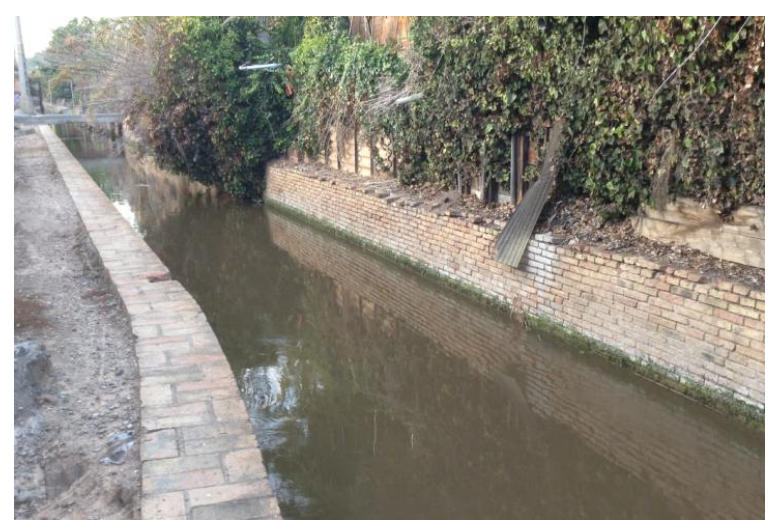

Figure 4 Present entrance of water into the Infanta Canal, at the mouth of the Riera de Rubí (see online version for colours)

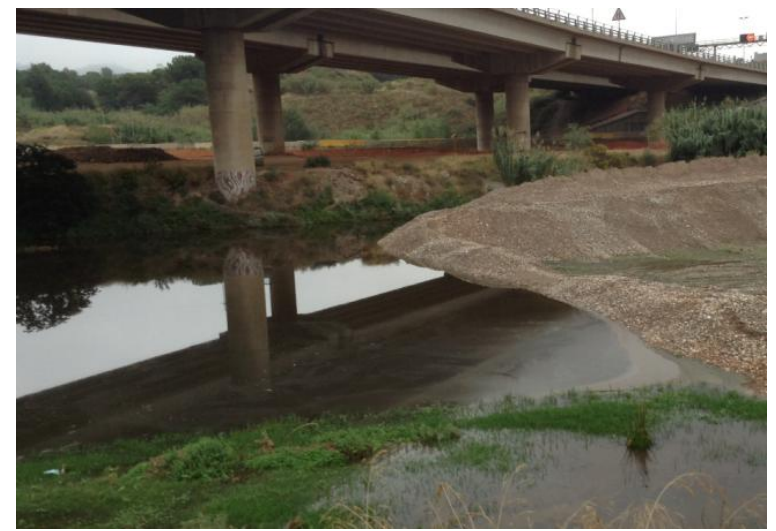

At present the canal catches the water $5 \mathrm{~km}$ upwards from the original site, near the place where Rubí torrent enters Llobregat river, where a temporary dike made of sand and stone diverts the water to the canal (Figure 4), because of the unsafe quality of the torrent water which carries treated and sometimes untreated, wastewater from several cities and industrial facilities upstream. By using the dike water of the torrent is not allowed to enter the Llobregat except in case of extreme flow (when it is diluted). Then the quality of the 
river water downwards is preserved, because it is the raw water that after treatment is supplied to part of Greater Barcelona (http://es.wikipedia.org/).

\section{The canal and its role on the economy of the area}

The existing farmland in the left side of the Llobregat river delta was irrigated through the principal and secondary canals of the distribution infrastructure. In order to increase the agricultural land available, as indicated before, several marshes and wetlands were desiccated by applying the existing laws at that time on land sanitation and recovery. An additional reason for desiccation, as indicated, was the presence at the time of vectors for malaria disease (mosquitoes), common in the area.

The lower Llobregat water is somewhat saline due to the presence of salt mines in the middle of the basin. Also, the neighbouring location of the sea exerts an influence on the salinity of the delta and all it counselled to let the lands fallow from time to time when the area was devoted to dry farmland. Once soils became irrigated this was no more necessary, since irrigation water cleaned the well-drained, mainly sandy, soils from salts through infiltration and percolation.

The foreseen 3,000 ha of land became irrigated quite entirely and the agricultural business was quickly developed. New crops were established and new cultivation practices were implemented. As indicated before, the good quality of soils for agricultural purposes, the neighbouring market in Barcelona and the mild climate, practically without frost episodes, which favoured even more the intensive agriculture as well as the availability of labour made possible to obtain several crops per year, which provided employment for people all seasons.

In summertime, the crops were artichokes, cereal and lettuces; really rewarding crops. The rest of the year more common crops were grown. Several areas in the upper parts of the system were planted with fruit trees. The yields used to be very good and consequently the markets of destination were quickly enlarged. The fruits and vegetables exportation to Europe started quite immediately, towards Sweden, Switzerland, Germany and France.

In terms of economy, once the financing period of the canal ended, the operation of it was really not expensive, since the only payment agreed was a fixed amount per irrigated hectare and year and not per amount of water used. Unexpected expenses were usually covered by the benefits of electricity generation.

By the end of 19th century, the economy of the entire zone was revitalised from the industrial point of view and especially by the arrival of a new railway to Molins de Rei in 1855. The railway ended at the Barcelona harbour which helped to increase even more the exportation of crops. The industries which started to be present in the area were the mills and sawmills using the generated hydropower and serving as auxiliary industry to agricultural practices. The agricultural surplus was used to prepare liquors by local distilleries (named 'fasinas'). Afterwards, the textile industries developed in the entire Llobregat basin, including the area of the delta. Even a paper mill was located in the canal area using the hydraulic energy for its activities. A secondary effect of this industry implementation was an increasing pressure to use agricultural land for building purposes (Suriol, 2003).

The Spanish Civil War (1936-1939), the Second World War, the increasing urbanisation of the area, the industrialisation and the proximity to Barcelona were 
reducing progressively the agricultural areas which by 2010 were only 300 hectares. All this agricultural area is located on the upper part of the old canal. Apart from it, the industrial revolution and the changes of energy sources made not necessary the energy generated by the Infanta Canal waters. It is also to take into account the big wave of immigration which reached Barcelona and its surrounding areas in the 60's and 70's of the 20th century nearly doubling the number of inhabitants. That was originated because of the heavy industrialisation of the area: the agriculture was no longer competitive with the residential and industrial uses of land. This negative circumstance was exacerbated by a nearly complete lack of urban, industrial and agricultural planning procedures.

In 1957 a new industrial area (Zona Franca) was created besides the harbour, near the river mouth, to build the SEAT automobile factory, which in turn favoured the implementation of the auxiliary industry. At that time the harbour expanded its facilities in the area of influence of the canal with the consequent additional reduction of the agricultural area. Similar actions were done in the neighbouring municipalities and as a result $90 \%$ of the rich agricultural lands on the Llobregat left side were converted into streets, buildings and industrial facilities (AHSEP, 1988). As a consequence, the Infanta Canal became an open air sewer, where all types of pollutants and rubbish could be found. In several areas the trace of the canal was filled with debris and disappeared.

The scarce surviving farmers were forced to build wells for having water for irrigation, but the successive enlargements of the harbour and an unlimited extraction of groundwater by the industries lead to a heavy salinisation of the aquifer which in turn made the land unproductive and abandoned in a number of areas but the upper part of the delta left side (http://bellvitgejose.blogspot.com.es/).

\section{Conclusions}

The industrial development, the railways, the uncontrolled urbanisation, several motorways and roads as well as the bad health conditions of the area; jointly with the budgetary difficulties of the affected municipalities condemned the canal to disappear in its final part. Scarcely 100 metres of it remain in Hospitalet de Llobregat town (Figure 5) from the original $4 \mathrm{~km}$ in that municipality (La Vanguardia Newspaper, 2012a, 2012b). A few remnants can also be found in the vicinity of Can Tunis Cemetery in Barcelona (Figure 6).

Only the farmers owning lands in the upper parts of the left side of the Llobregat delta are still using water of the Infanta Canal for irrigation.

This description demonstrates the difficulties encountered in the Mediterranean to keep agriculture from the demands of flat surfaces to develop industry, towns and tourism facilities. In turn, the degradation of land is creating additional problems, due to desertification (big paved surfaces) and destruction of water management infrastructures. 
Figure 5 Remnants of the channel in Hospitalet de Llobregat (see online version for colours)

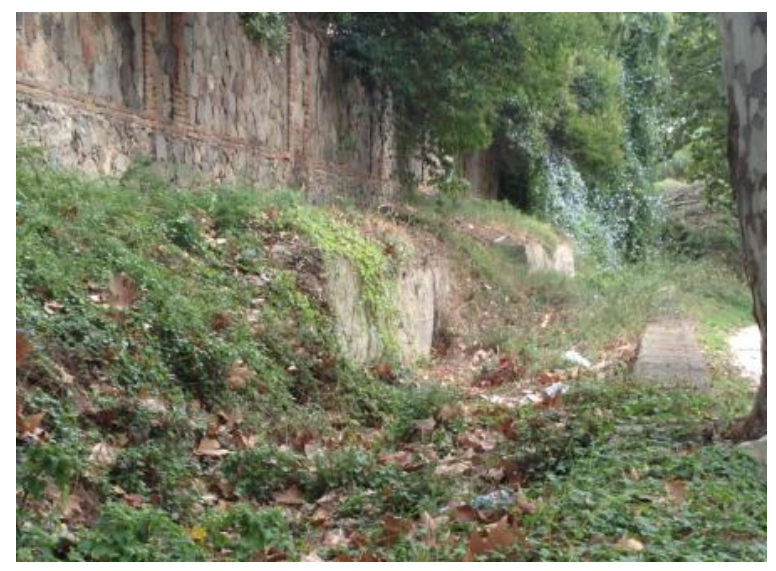

Figure 6 The Infanta Canal besides the Can Tunis Cemetery, in Barcelona (see online version for colours)

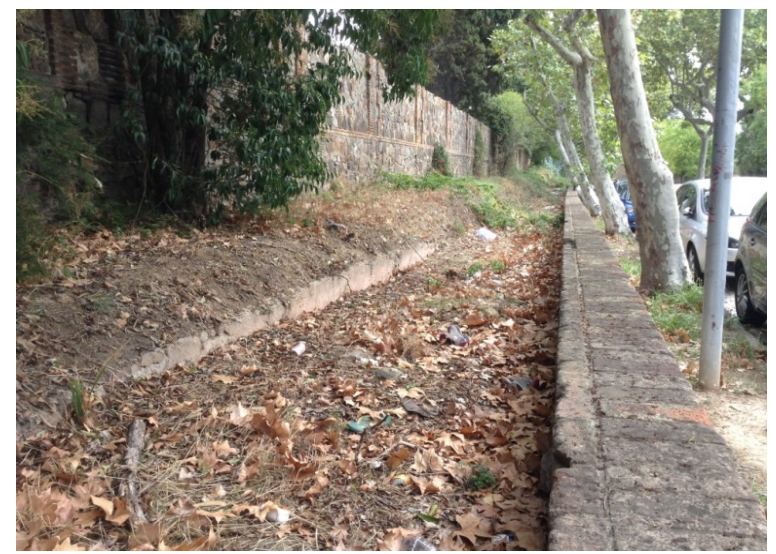

The water quality is also affected due to salinisation from different origins, pollution derived from air pollutants settling in the flat surfaces, lack of infiltration and other negative circumstances. From time to time there appear problems of flood appear due to the destruction of natural and old drainage infrastructures, considering also the lack of slopes, typical from the delta areas near the sea (TVC, 2011).

There is a need to recover the old infrastructures of water management, which exerted several functions in the management and especially distribution of water in the flat areas near the sea. The one described is a typical case of lack of care of water management remnants. 


\section{References}

Suriol, J. (2003) El Canal de la Infanta, pp.423-432, Actes de la VII trobada d'Història de la Ciència i la Tècnica, SCHCT, Barcelona.

Arxiu Històric de Santa Eulàlia de Provençana (AHSEP) (1988) El desenvolupament de l'esquerra de la Comarca del Baix Llobregat, de la ciutat de l'Hospitalet i de la pròpia barriada de Santa Eulàlia.

http://bellvitgejose.blogspot.com.es/2009/01/12-el-uso-energetico-del-canal-de-la.html (accessed 30 March 2013).

http://es.wikipedia.org/wiki/Canal_de_la_Infanta (accessed 30 March 2013).

Institut Cartogràfic de Catalunya (ICC) (2013) Fons Històrics, Mapes de Catalunya (s.16-20) Mapa Real Canal de la Infanta Luisa Carlota de Borbón 1908.

La Vanguardia Newspaper (2012a) El Canal de la Infanta, un patrimonio histórico en peligro, 27 February.

La Vanguardia Newspaper (2012b) L'Hospitalet recuperará el Canal de la Infanta, 29 June.

Televisió de Catalunya (TVC) (2011) Reivindican el Canal de la Infanta como Patrimonio Histórico del baix Llobregat, 30 October. 